\title{
Analyzing the concept of fluid overload in Chronic Kidney Disease patients in dialysis therapy: an integrative review
}

\author{
Análise do conceito sobrecarga de líquidos em pacientes com doença renal crônica em terapia \\ dialítica: revisão integrativa \\ Análisis del concepto sobrecarga de líquidos en pacientes con enfermedad renal crónica en terapia \\ dialítica: revisión integrativa
}

Maria Isabel da Conceição Dias Fernandes ${ }^{1}$, Bertha Cruz Enders ${ }^{1}$, Ana Luisa Brandão de Carvalho Lira ${ }^{1}$

How to cite this article:

Fernandes MICD, Enders BC, Lira ALBC. Analyzing the concept of fluid overload in Chronic Kidney Disease patients in dialysis therapy: an integrative review. Rev Esc Enferm USP. 2017;51:e03299. DOI: http://dx.doi.org/10.1590/S1980-220X2016036003299

${ }^{1}$ Universidade Federal do Rio Grande do Norte, Departamento de Enfermagem, Programa de Pós-Graduação em Enfermagem, Natal, RN, Brazil.

\begin{abstract}
Objective: To analyze the concept of fluid overload in Chronic Kidney Disease patients undergoing dialysis therapy and comparing it to the Nursing Diagnosis of Excess fluid volume present in the NANDA International. Method: An integrative literature review carried out in the LILACS, CINAHL and SCOPUS databases. Results: The sample was comprised of 22 articles. The defining attributes of the concept were: fluid retention, fluid buildup in the body, and weight gain over a short period; while the attributes composing the definition were: fluid retention in the body (intracellular/extracellular space) expressed by weight gain over short period of time. Twenty-one (21) antecedents and 22 consequents of fluid overload in patients with renal disease in dialysis therapy were identified. Conclusion: The definition evidenced by the NANDA International taxonomy for the Excess fluid volume Nursing Diagnosis and the components of this diagnosis need to be complemented in order to better target the care of patients with kidney disease undergoing dialysis therapy.
\end{abstract}

DESCRIPTORS

Nursing Diagnosis; Chronic Kidney Disease; Renal Dialysis; Review.
Corresponding author:

Maria Isabel da Conceição Dias Fernandes

Campus Universitário, S/N, Lagoa Nova

CEP 59072-970 - Natal, Rio

Grande do Norte, Brazil

bebel_6@hotmail.com 


\section{INTRODUCTION}

The nursing diagnosis Excess fluid volume, classified by the NANDA International in the domain of nutrition and class of hydration ${ }^{(1)}$, was identified in $82 \%$ of terminal Chronic Kidney Disease patients undergoing hemodialysis in a study on the subject, representing a high prevalence of this problem among these subjects ${ }^{(2)}$. However, of the 25 clinical indicators included in this diagnosis, only eight had a significant association, being: restlessness, pulmonary congestion, jugular vein distention, edema, electrolyte imbalance, weight gain over a short period of time, intake exceeds output and adventitious breath sounds ${ }^{(1-2)}$.

In addition, another study states that the indicators azotemia, a decrease in hematocrit, a decrease in hemoglobin and anxiety are not accurate for establishing the diagnosis of Excess fluid volume in dialysis patients ${ }^{(3)}$, despite being included in the taxonomy of NANDA International for this diagnosis ${ }^{(1)}$.

In this sense, it is necessary to confirm the relationship between the characteristics not considered as being significant for Excess fluid volume in Chronic Kidney Disease patients undergoing dialysis, as well as to identify whether there are other components in addition to those presented by NANDA International. Thus, performing a conceptual analysis is pointed out as a recommended research technique for reviewing nursing diagnoses ${ }^{(4-5)}$.

Concept analysis encourages communication between professionals about certain phenomena. Therefore, considering it is a process that examines the basic elements of a concept, it helps to define obscure concepts, allowing for building hypotheses that accurately reflect the relations between the concepts. Thus, it enables the development of a standardized language capable of accurately describing nursing practice. Consequently, the exhaustive analysis of some concept for any potential diagnosis, intervention or nursing result facilitates the taxonomic work, providing a strong evidence base ${ }^{(5)}$.

As a result in light of the above, this study is relevant due to the need to better clarify the nursing diagnosis of Excess fluid volume and its components in Chronic Kidney Disease patients undergoing dialysis, so that nursing professionals can diagnose it with greater clarity. Furthermore, a concept is always an unfinished product given the transience of knowledge, and which undergoes transformations due to changes in the cultural, social or scientific context of each period ${ }^{(5)}$. In this regard, although NANDA International revised this diagnosis in $2013^{(1)}$, we believe that a revision is necessary in view of the previously reported divergences and gaps between the components of Excess fluid volume and the patients with Chronic Kidney Disease undergoing dialysis.

From this perspective, the study hypothesis is that the nursing diagnosis of Excess fluid volume presented by the NANDA International when related to Chronic Kidney Disease patients undergoing dialysis therapy has a distinct definition expressed by the taxonomy with other related factors and defining characteristics.

Therefore, we ask: Is the definition of Excess fluid volume nursing diagnosis from NANDA International adequate for
Chronic Kidney Disease patients undergoing dialysis therapy? What are attributes of the diagnostic condition that can define it? Are the related factors and defining characteristics existing in the NANDA International for this diagnosis sufficient or are there indispensable additions when relating to these specific patients? Thus, the objective of this study is to analyze the concept of fluid overload in Chronic Kidney Disease patients undergoing dialysis therapy and compare it to the nursing diagnosis of Excess fluid volume presented in the NANDA International.

\section{METHOD}

This is a concept analysis based on eight steps, including: 1 - concept selection; 2 - determining the analysis objectives; 3 -identification of possible uses of the concept; 4 - determining the essential attributes of the concept; 5 - constructing a model case; 6 - constructing a contrary case; 7 -identifying the concept consequents and antecedents; and finally, 8 - construction of empirical references to the concept attributes ${ }^{(5)}$. All the referred steps were carried out in conducting this study, except for constructing empirical references, since it did not related to the scope of our objective.

The concept of fluid overload was selected in the first step as it represents the conceptual core and the judgment element related to the nursing diagnosis of Excess fluid volume. For some authors, a concept is not exactly a nursing diagnosis, but rather inserted in the diagnostic heading coexisting with a conceptual core responsible for establishing relationships between antecedents and consequents. Thus, for the purposes of conducting a conceptual analysis of a nursing diagnosis, the conceptual nucleus is used in conjunction with the element judgment, so that the analysis focuses more accurately on the nursing diagnosis to be studied and there is no risk of seeking a concept that does not meet the intended proposal ${ }^{(4)}$.

The analysis objective was stipulated in the second step, which was to analyze the concept of fluid overload in Chronic Kidney Disease patients undergoing dialysis therapy. Concept uses were elucidated in the third step, identifying the areas in which the concept was commonly used. Critical concept attributes were verified in the fourth step. In the fifth and sixth steps, fictitious cases about the concept of fluid overload were constructed, seeking to assist in the process of constructing the definition of the studied concept. Finally, the proposed concept consequents and antecedents were highlighted in the seventh step.

We emphasize that identifying the attributes was crucial for defining the studied concept, since these are key elements responsible for nurses being able to establish the diagnosis ${ }^{(4-5)}$. Antecedents are the etiological factors, while consequents are the defining characteristics when comparing the taxonomy of NANDA International ${ }^{(5)}$.

The integrative review method was used for constructing the cases, determining the uses, attributes, consequents and antecedents of the Fluid overload concept. Thus, the following steps were carried out: identifying the review questions, searching the literature, categorizing the studies, evaluating the studies included in the review, analyzing the findings and then synthesizing the assessed knowledge ${ }^{(6)}$. 
For this review, the following questions were asked: What are the possible uses of the Fluid overload concept in Chronic Kidney Disease patients undergoing dialysis therapy? What are the attributes of the Fluid overload concept in Chronic Kidney Disease patients undergoing dialysis therapy, and are they definable? And finally, what are the antecedents and consequents of the Fluid overload concept in Chronic Kidney Disease patients undergoing dialysis therapy?

Faced with these questions, a single search was carried out in July 2017 in the LILACS (Latin American and Caribbean Health Sciences Literature), CINAHL (Cumulative Index to Nursing and Allied Health Literature) and SCOPUS databases, using the non-indexed keywords: Fluid retention and Fluid overload; and the indexed descriptors in the Medical Subject Headings (MeSH): Kidney Failure, Chronic, which were crossed using the Boolean operator AND, with the following combinations: Fluid retention AND Kidney Failure, Chronic and Fluid overload AND Kidney Failure, Chronic. It should be noted that the non-indexed keywords Fluid Retention and Fluid overload in the LILACS, and the descriptor Chronic renal failure indexed in the Descriptors in Health Sciences (DeCS) were used. These databases were accessed through the Coordination Portal for the Improvement of Higher Education Personnel (CAPES - Coordenação de Aperfeiçoamento de Pessoal de Nivel Superior).

The search was developed by three evaluators, the researcher and two nurses, who accessed each database simultaneously and exhausted each database in a single day with the purpose of conferring greater reliability to the article selection process. In this search, each evaluator read titles and abstracts of articles, and each evaluator individually accepted the article to compose the sample when the items proposed by the relevance test were met. In this test, the article should at least answer one of the guiding questions proposed in this study, and pre-established inclusion/exclusion criteria should be met.

The inclusion criteria implemented were: complete articles available in the selected databases; articles in Portuguese, English or Spanish; and studies that addressed the concept of Fluid overload in Chronic Kidney Disease patients undergoing dialysis therapy, in addition to some/ all of the following items being present: uses, consequents, antecedents, and/or essential concept attributes.
The following exclusion criteria were also considered: editorials, letters to the editor, abstracts, expert opinions, and integrative reviews.

After individual and blind selection of the three evaluators, a comparison between the articles included in each of their samples was performed. In the case of differences in the selected articles, the evaluators conducted a thorough reading of the article under discussion and reached a consensus among them. The article was included in the sample when at least two evaluators agreed to accept it.

Finally, the evaluators identified 653 articles in the selected databases and 22 articles were included, as shown in Figure 1.

For the extraction of the key elements contained in each article, an instrument was implemented considering the following items: characterization of the studies (year of publication, country, age range of the subjects, number of cases, type of dialysis, method and level of evidence) and data on uses, attributes, and concept antecedents and consequents.

The evidence levels were classified according to the Joanna Briggs Institute, namely: Level 1 - Experimental studies; Level 2 - Quasi-experimental studies; Level 3 - Analyticalobservational studies; Level 4 - Observational/descriptive studies; Level 5 - Expert opinion and research bank ${ }^{(7) .}$

The articles selected and recorded for this research were submitted to analysis and interpretation. For the analysis, the extracted data were interpreted according to the steps proposed by the theoretical reference of Walker and Avant ${ }^{(5)}$, so that the uses and the essential attributes of the Fluid overload concept were synthesized with the aim of developing a definition of this concept, as well as to stratify the antecedents and consequents of the analyzed concept.

The most cited consequents for fluid overload in the review, as well as the main attribute were used for constructing the model case. For construction of the contrary case intended to deny the presence of fluid overload, the main attribute of the concept was denied and the most prevalent consequents of the revision were absent.

Finally, the definition as well as the antecedents and the consequents of the fluid overload concept were compared to the defining characteristics, related factors and nursing diagnosis definition of Excess fluid volume in the NANDA International.

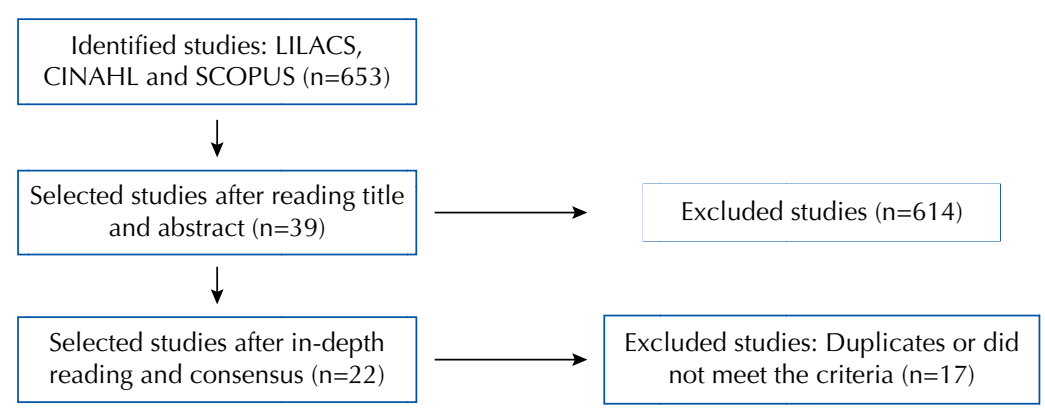

Figure 1 - Flowchart of the study selection process - Natal, Rio Grande do Norte, Brazil, 2017. 


\section{RESULTS}

The analyzed studies originated predominantly in Europe, comprising a total of $36.3 \%$. North America accounted for $31.8 \%$, with the United States accounting for $27.2 \%$. On the other hand, Asia and South America had rates of $22.7 \%$ and $4.5 \%$, respectively. One hundred percent of the studies were published in English.

Regarding the year of publication, $68.1 \%$ of the studies were published in the last 10 years between 2007 and 2017, especially in the year 2012, which produced $18.1 \%$ of the studies; however, there were studies since 1992. In relation to the age group, the majority of the participants (95.4\%) were adults, and $4.5 \%$ were children/adolescents. The prevalent type of dialysis was hemodialysis treatment (90.9\%).
Regarding the study designs, cross-sectional studies were predominant (40.9\%), with an emphasis on evidence level four (54.5\%). In addition to cross-sectional studies, case studies (9.0\%) and qualitative studies (4.5\%) also ranked at this level of evidence ${ }^{(7)}$.

The characterization and results (uses and attributes of the concept) of the selected studies are presented in Chart 1.

Regarding the uses of the fluid overload concept, most of the studies were performed in the medicine area (63.6\%), while the nursing area conducted $36.3 \%$ of these studies. Regarding the attributes identified for the proposed concept, $68.1 \%$ of the 22 analyzed publications presented the concept attributes. Among the most cited attributes were fluid retention in 36.3\% of the publications, and fluid accumulation in the body in $13.6 \%$.

Chart 1 - Characterization and results of the articles selected for the analysis of fluid overload concept in Chronic Kidney Disease patients undergoing dialysis therapy - Natal, Rio Grande do Norte, Brazil, 2017.

\begin{tabular}{|c|c|c|c|c|c|c|c|c|}
\hline Year & Country & Method & $\begin{array}{l}\text { Evidence } \\
\text { Level }\end{array}$ & Cases & Age group & Type of dialysis & $\begin{array}{l}\text { Concept } \\
\text { Uses }\end{array}$ & Concept Attributes \\
\hline $1992^{(8)}$ & Germany & Quasi-experimental & Level 2 & 18 & $\begin{array}{l}\text { Children and } \\
\text { adolescents }\end{array}$ & Hemodialysis & Medicine & - \\
\hline $1995^{(9)}$ & USA & Cross-sectional study & Level 4 & 42 & Adults & Hemodialysis & Medicine & $\begin{array}{l}\text { Fluid accumulation in the } \\
\text { body; Weight gain over a } \\
\text { short period of time. }\end{array}$ \\
\hline $2002^{(10)}$ & USA & Clinical pseudo essay & Level 1 & 468 & Adults & Hemodialysis & Medicine & $\begin{array}{l}\text { Weight gain over a } \\
\text { short period of time. }\end{array}$ \\
\hline $2005^{(11)}$ & Greece & Cross-sectional study & Level 4 & 70 & Adults & Hemodialysis & Nursing & $\begin{array}{l}\text { Weight gain over a } \\
\text { short period of time. }\end{array}$ \\
\hline $2005^{(12)}$ & China & Quasi-experimental & Level 2 & 58 & Adults & $\begin{array}{c}\text { Peritoneal } \\
\text { dialysis }\end{array}$ & Medicine & $\begin{array}{l}\text { Weight gain over a } \\
\text { short period of time. }\end{array}$ \\
\hline $2006^{(13)}$ & USA & Case study & Level 4 & 01 & Adults & Hemodialysis & Nursing & Fluid retention. \\
\hline $2006^{(14)}$ & Brazil & Cross-sectional study & Level 4 & 74 & Adults & Hemodialysis & Nursing & - \\
\hline $2007^{(15)}$ & USA & Case study & Level 4 & 01 & Adults & Hemodialysis & Nursing & $\begin{array}{l}\text { Fluid accumulation; Increased } \\
\text { extracellular/intracellular } \\
\text { volume; Weight gain over a } \\
\text { short period of time. }\end{array}$ \\
\hline $2009^{(16)}$ & USA & Cohort study & Level 3 & 34,107 & Adults & Hemodialysis & Medicine & $\begin{array}{l}\text { Fluid retention; Weight gain over } \\
\text { a short period of time. }\end{array}$ \\
\hline $2009^{(17)}$ & Sweden & $\begin{array}{c}\text { Retrospective } \\
\text { observational study }\end{array}$ & Level 3 & 4,498 & Adults & Hemodialysis & Medicine & $\begin{array}{l}\text { Fluid retention; Weight gain over } \\
\text { a short period of time. }\end{array}$ \\
\hline $2010^{(18)}$ & Sweden & Cross-sectional study & Level 4 & 133 & Adults & Hemodialysis & Nursing & $\begin{array}{l}\text { Weight gain over a } \\
\text { short period of time. }\end{array}$ \\
\hline $2010^{(19)}$ & $\begin{array}{l}\text { United } \\
\text { Kingdom }\end{array}$ & Qualitative study & Level 4 & 30 & Adults & Hemodialysis & Nursing & - \\
\hline $2011^{(20)}$ & Ireland & Cross-sectional study & Level 4 & 79 & Adults & Hemodialysis & Nursing & Fluid retention. \\
\hline $2012^{(21)}$ & England & Cross-sectional study & Level 4 & 115 & Adults & $\begin{array}{l}\text { Peritoneal } \\
\text { dialysis }\end{array}$ & Medicine & - \\
\hline $2012^{(22)}$ & South Korea & Observational study & Level 3 & 172 & Adults & Hemodialysis & Medicine & $\begin{array}{l}\text { Fluid retention; Weight gain over } \\
\text { a short period of time. }\end{array}$ \\
\hline $2012^{(23)}$ & Iran & $\begin{array}{l}\text { Quasi-experimental } \\
\text { study }\end{array}$ & Level 2 & 63 & Adults & Hemodialysis & Nursing & $\begin{array}{l}\text { Fluid accumulation in the body; } \\
\text { Fluid retention; Weight gain over } \\
\text { a short period of time. }\end{array}$ \\
\hline $2012^{(24)}$ & Canada & Cross-sectional study & Level 4 & 26 & Adults & Hemodialysis & Medicine & Fluid retention. \\
\hline $2013^{(25)}$ & Austria & Cross-sectional study & Level 4 & 244 & Adults & Hemodialysis & Medicine & - \\
\hline $2013^{(26)}$ & China & Cross-sectional study & Level 4 & 112 & Adults & Hemodialysis & Medicine & - \\
\hline $2014^{(27)}$ & Taiwan & Observational study & Level 3 & 472 & Adults & Hemodialysis & Medicine & - \\
\hline $2015^{(28)}$ & USA & Observational study & Level 3 & 39,256 & Adults & Hemodialysis & Medicine & $\begin{array}{l}\text { Fluid retention; Weight gain over } \\
\text { a short period of time. }\end{array}$ \\
\hline $2017^{(29)}$ & $\begin{array}{l}\text { Multi- } \\
\text { centric }\end{array}$ & Cohort study & Level 3 & 21,919 & Adults & Hemodialysis & Medicine & $\begin{array}{l}\text { Weight gain over a } \\
\text { short period of time. }\end{array}$ \\
\hline
\end{tabular}


We can highlight that the consequent weight gain in a short period of time was present in $54.5 \%$ of the studies, and it was also considered as an essential concept attribute considering its high frequency in the articles, indicating an important relationship with the presence of fluid overload in Chronic Kidney Disease patients undergoing dialysis therapy. The exact amount of liquids considered as excess was not clarified in the studies.

The following chart was constructed regarding the model case and the contrary case:

Chart 2 - Model case and contrary case directed toward the concept of fluid overload in Chronic Kidney Disease patients undergoing dialysis therapy - Natal, Rio Grande do Norte, Brazil, 2017.

\begin{tabular}{|l|l|}
\hline \multicolumn{1}{|c|}{ Model case } & \multicolumn{1}{|c|}{ Contrary case } \\
\hline $\begin{array}{l}\text { J. C., male patient, } 50 \text { years old, with Chronic Kidney Disease and on } \\
\text { hemodialysis for } 16 \text { years. He presented a weight gain in the last } 48 \\
\text { hours, blood pressure of 222/142 mm of mercury, heart rate of } 110 \text { per } \\
\text { minute and respiratory rate of } 24 \text { movements per minute; the presence } \\
\text { of fine crackles in pulmonary auscultation; flat abdomen with hydroaeric } \\
\text { noises present, no visceromegalias; edema in the lower limb (+2/+4). } \\
\text { The electrocardiogram revealed left ventricular hypertrophy. }\end{array}$ & $\begin{array}{l}\text { J. B., male patient, 22 years old } \\
\text { hemodialysis treatment for 2 years. He presented azotemia, weight } \\
\text { loss of } 0.5 \text { kilograms in the last 48 hours and reports of diarrhea. Upon } \\
\text { examination he demonstrated to be conscious, oriented, normocardial, } \\
\text { normotensive, eupneic and afebrile; cardiac auscultation showed two- } \\
\text { beat normo-phonemic sounds without blows; pulmonary auscultation } \\
\text { showesence of vesicular murmurs throughout the pulmonary } \\
\text { extension; percussion showed clear lung sounds; palpation showed good } \\
\text { pulmonary expansion; flat abdomen, hepatomegaly to deep palpation, } \\
\text { normoactive hydroaeric noises; edema-free limbs. }\end{array}$ \\
\hline
\end{tabular}

Considering the model case, it can be noticed that the patient presents fluid overload considering the presence of fluid retention mainly expressed by weight gain in a short period, in addition to other evidence concerning fluid accumulation such as edema, high blood pressure, crackles, tachypnea and heart disease. In the contrary case, the studied concept attributes or other signs of liquid retention are not identified. It is worth pointing out that these are fictitious cases, merely illustrative in order to better clarify the concept.

Based on the attributes described by the literature for the fluid overload concept and according to the model and contrary cases, the following definition was constructed: fluid retention in the body (intracellular/extracellular space), expressed by weight gain in a short period.
Charts 3 and 4 present the antecedents and consequents of the fluid overload concept found in the literature in association with the related factors and the defining characteristics expressed by the NANDA International taxonomy regarding the Excess fluid volume diagnosis ${ }^{(1)}$.

According to the data from Chart 3, there are 21 Fluid overload concept antecedents, of which the ones with higher prevalence were: excess fluid intake presented in $36.3 \%$ of the articles, diet rich in sodium, decreased glomerular filtration rate and diabetes in $18.1 \%$ each, and difficulty in the adherence to fluid restrictions in $13.6 \%$. Of these, only the first three corresponded to the related factors included in the NANDA International ${ }^{(1)}$.

Chart 3 - Antecedents of the fluid overload concept in Chronic Kidney Disease patients undergoing dialysis therapy and related factors of the Excess fluid volume nursing diagnosis present in the NANDA International - Natal, Rio Grande do Norte, Brazil, 2017.

\begin{tabular}{|c|c|}
\hline Antecedents & Related Factors (NANDA International) ${ }^{(1)}$ \\
\hline Increased renin-angiotensin-aldosterone in the blood (1 article $)^{(13)}$ & - \\
\hline \multicolumn{2}{|l|}{ Increase in the sodium concentration of the dialysate $(1 \text { article })^{(29)}$} \\
\hline Low self-efficacy $(1 \text { article })^{(18)}$ & - \\
\hline Comorbidities $(1 \text { article })^{(25)}$ & - \\
\hline Diabetes $(4 \text { articles })^{(12,16-17,22)}$ & - \\
\hline Diet high in sodium $(4 \text { articles })^{(13,14-15,22)}$ & Excess sodium intake \\
\hline Difficulty in adherence to the restrictions of fluids ( 3 articles) $)^{(17,20,23)}$ & - \\
\hline Decreased glomerular filtration rate $(4 \text { articles })^{(13,18,23,27)}$ & $\begin{array}{l}\text { Compromised regulatory } \\
\text { mechanism }\end{array}$ \\
\hline Daily stress $(1 \text { article) })^{(9)}$ & - \\
\hline Lack of guidelines by the nutritionist (1 article $)^{(11)}$ & - \\
\hline Intermittent hemodialysis $\left(1\right.$ article) ${ }^{(28)}$ & - \\
\hline Men $(1 \text { article })^{(16)}$ & - \\
\hline High protein intake $\left(1\right.$ article) ${ }^{(16)}$ & - \\
\hline Young individuals $\left(2\right.$ articles) ${ }^{(14,17)}$ & - \\
\hline Excess fluid intake $(8 \text { articles })^{(9,13-18,22)}$ & Excess fluid intake \\
\hline Greater experience in dialysis treatment $(1 \text { article })^{(17)}$ & - \\
\hline Lower body mass index $(1 \text { article })^{(17)}$ & - \\
\hline 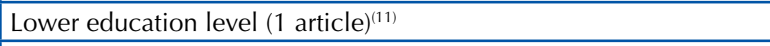 & - \\
\hline Non-adherence to hemodialysis $(1 \text { article })^{(28)}$ & - \\
\hline Inaccurate dry weight prescription $(1 \text { article })^{(15)}$ & - \\
\hline Proteinuria (1 article) $)^{(13)}$ & - \\
\hline
\end{tabular}


Regarding the consequents of the fluid overload concept in Chronic Kidney Disease patients undergoing dialysis therapy, 22 were identified in the literature, in which those with the highest prevalence were weight gain in a short period (54.5\%), increased blood pressure in $45.4 \%$, and cardiovascular diseases in $31.8 \%$. Among the found consequents, 10 corresponded with the defining characteristics presented by NANDA International. Among those the most cited, only the weight gain and the increase in pressure corresponded to the characteristics from NANDA International ${ }^{(1)}$, as shown in Chart 4.

Chart 4 - Fluid overload concept consequents in Chronic Kidney Disease patients undergoing dialysis therapy and defining characteristics of the Excess fluid volume nursing diagnosis present in the NANDA International - Natal, Rio Grande do Norte, Brazil, 2017.

\begin{tabular}{|c|c|}
\hline Consequents & Defining characteristics (NANDA International) \\
\hline Obstructive sleep apnea (1 article) $)^{(24)}$ & - \\
\hline Increased Blood Pressure (10 articles $)^{(8-10,12-15,17,20,28)}$ & Alteration in blood pressure \\
\hline Increased D-dimer (1 article $)^{(25)}$ & - \\
\hline Increased atrial natriuretic peptide in plasma (2 articles) ${ }^{(8,25)}$ & - \\
\hline Increased Cerebral Natriuretic peptide in plasma $(1 \text { article })^{(21)}$ & - \\
\hline Pulmonary congestion (5 articles) $)^{(8,13,15,20,28)}$ & Pulmonary congestion \\
\hline Pulmonary crackles (1 article) $)^{(13)}$ & Adventitious breath sound \\
\hline Decrease in hemoglobin $(1 \text { article })^{(22)}$ & Decrease in hemoglobin \\
\hline Decrease in oxygen partial pressure $(\mathrm{PaO} 2)(1 \text { article })^{(13)}$ & - \\
\hline Dyspnea (6 articles) $)^{(8-9,15,19-20,23)}$ & Dyspnea \\
\hline Cardiovascular diseases (7 articles) $)^{(9,13,19,23,25-26,28)}$ & - \\
\hline Generalized edema (1 article) $)^{(23)}$ & Anasarca \\
\hline Peripheral edema ( 6 articles $)^{(8,12-13,14-15,19)}$ & Edema \\
\hline Endotoxemia (1 article) $)^{(14)}$ & - \\
\hline Weight gain over a short period of time (12 articles) $)^{(9-12,15-18,22-23,28-29)}$ & Weight gain over a short period of time \\
\hline Low levels of serum albumin (1 article $)^{(25)}$ & - \\
\hline $\begin{array}{l}\text { Electrolyte levels: hyponatremia and increase in phosphorus } \\
(2 \text { articles })^{(13,22)}\end{array}$ & Electrolyte imbalance \\
\hline Presence of S3 (1 article) $)^{(13)}$ & Presence of S3 heart sound \\
\hline Presence of Troponin T (1 article $)^{(25)}$ & - \\
\hline Tachycardia (2 articles) $)^{(8,13)}$ & - \\
\hline Tachypnea (2 articles) ${ }^{(13,15)}$ & - \\
\hline Cough $(1 \text { article })^{(15)}$ & - \\
\hline
\end{tabular}

\section{DISCUSSION}

Regarding the identified definition for the Fluid overload concept in Chronic Kidney Disease patients undergoing dialysis therapy, we noticed that it is quite similar to that employed for Excess fluid volume in the NANDA International, which is: "Increased isotonic fluid retention"(1). However, even though the definitions are similar, the constructed concept in the present study is directed more accurately to patients with Chronic Kidney Disease undergoing dialysis therapy.

Fluid overload has a high prevalence in patients submitted to hemodialysis, with frequencies above $80 \%$ verified in the literature ${ }^{(2,14,30)}$. The occurrence of volume overload is strongly associated with increased risk of mortality and morbidity in individuals with Chronic Kidney Disease, a reality with deep clinical and economic implications ${ }^{(16,22-23,28)}$. Among hemodialysis patients in the United States, treatment for fluid overload is common and expensive, where the average cost is
$\$ 6,372.00$ per episode, and having total costs of approximately $\$ 266,000.000^{(31)}$.

Thus, early and accurate detection of fluid overload antecedents is important. In this analysis, the highlighted antecedents of this concept were Excess fluid intake, Diets high in sodium and a Decrease in the rate of glomerular filtration, as pointed out by the NANDA International ${ }^{(1)}$. The decrease in glomerular filtration rate (GFR) is inherent to Chronic Kidney Disease patients due to impaired renal function. Thus, as the kidney function declines, the filtration also decreases ${ }^{(32)}$.

Difficulty in adherence to fluid restrictions has also been reported as prevalent, although not pointed out by the NANDA International. In this aspect, authors reveal that the difficulty in adhering to the diet and fluid restrictions is a constant reality in the life of patients undergoing hemodialysis, and is considered by the literature as the most difficult component in the therapeutic plan of these patients due to a series of factors such as food preferences, lifestyle and cultural values ${ }^{(16,20)}$. 
In this perspective, this difficulty in adherence is probably related to consuming diets rich in sodium and to excess fluid intake. Among the major causes of excess fluid intake is excess sodium intake, which raises sodium serum levels, causing a hypertonic state with consequent additional fluid intake ${ }^{(33)}$. Excess hydration among renal patients may also result from the presence of hyperglycemia, a sign mainly identified in diabetic patients responsible for increasing fluid consumption by hemodialysis patients ${ }^{(12)}$.

There is a clear relationship between dietary sodium intake and elevated blood pressure. Thus, the restriction, mainly of sodium, is associated with an improvement in fluid volume, blood pressure control and improvement in cardiac function ${ }^{(33)}$. The authors confirm this proposition by ratifying the relationship between dietary sodium restriction and the extent of volumetric control and blood pressure in the body; they also report the important role of sodium control in preventing abnormal remodeling in the ventricles, ventricular hypertrophy, heart failure and increased arterial stiffness ${ }^{(34)}$.

In accordance with the signs and symptoms reported above, this study identified cardiovascular diseases, increased blood pressure, and short-term weight gain as the main consequents of fluid overload in patients with Chronic Kidney Disease undergoing dialysis therapy. Although other consequents have been identified corresponding to the defining characteristics of NANDA International, only the most cited will be discussed in this review: weight gain and increase in blood pressure.

Regarding the consequent increase in blood pressure, a study reveals that differences in blood pressure between Chronic Kidney Patients on hemodialysis are partial reflections between the differences in the volume state, and that blood pressure usually decreases during hemodialysis with the removal of fluids ${ }^{(10)}$. Thus, hypertension may be a result of increased fluid retention and/or stimulation of the renin-angiotensin-aldosterone system ${ }^{(13)}$.

Weight gain in a short period between two consecutive hemodialysis sessions is common in the patients under discussion, and it represents the most frequently studied adherence measure of fluid consumed by hemodialysis patients since it is considered an indirect measure of fluid intake ${ }^{(16)}$. Because these patients have non-functional kidneys and little or no urine is excreted, some fluid is expected to be acquired between dialysis sessions ${ }^{(9)}$. Thus, in patients undergoing conventional hemodialysis, it is unlikely that this weight gain is due to factors other than interdialytic fluid gain ${ }^{(16)}$.

High levels of daily stress contribute to increased weight gain. Patients on hemodialysis who have stressful events in their daily life present changes in their daily plans, and when inefficiently confronted they abandon treatment and/ or abuse their diet or the fluid regimen ${ }^{(9)}$.

Moreover, another study evidences the potent association between fluid retention expressed by weight gain, and the higher risk of cardiovascular events, particularly heart failure $^{(28)}$. A study on fluid gain between dialysis and the risk of cardiovascular death found that an interdialytic weight gain above $4.0 \mathrm{~kg}$ in more than two consecutive dialysis sessions was associated with a $28 \%$ risk of death ${ }^{(16)}$.
Thus, fluid overload has emerged as a parameter that strongly correlates with cardiovascular biomarkers. A study shows that excess fluid is associated with higher levels of biomarkers of cardiac muscle decomposition and ischemia, supporting the hypothesis that fluid overload plays a significant role in generating and increasing vascular and cardiac damage ${ }^{(25)}$.

Thus, when examining the pathophysiological mechanisms that point to increased fluid retention and death from cardiovascular causes, it is necessary that effective strategies are defined to mitigate fluid retention, leading to a consequent improvement in the evolution of patients on dialysis ${ }^{(16)}$. Therefore, conducting studies that establish the causal relations between fluid overload and its antecedents is recommended, in order to confirm this link between Chronic Kidney Disease patients undergoing dialysis therapy, since it will help in planning nursing care directed to these patients.

In view of the findings of this study, we foresee amplification in the terminology regarding the nursing diagnosis of Excess fluid volume present in NANDA International when viewed from the perspective of the Chronic Kidney Disease patients undergoing dialysis therapy. Thus, terms commonly used in nursing were supported by evidence from the scientific literature in this study, offering better reflection on the clinical conditions identified in these patients. The best available evidence on this theme will assist nurses in the process of diagnostic inference and patient care.

As a limitation of this study, we can point out not using the diagnostic title as a concept in itself for the purposes of conceptual analysis.

\section{CONCLUSION}

Fluid overload presented the main attributes of: fluid retention, fluid accumulation in the body and weight gain over a short period of time. The concept was defined as: fluid retention in the body (intracellular/extracellular space), expressed by weight gain in a short period.

We have identified 21 antecedents in the literature for the fluid overload concept in Chronic Kidney Disease patients undergoing dialysis therapy, with emphasis on excess fluid intake, high sodium diet, decreased glomerular filtration rate, difficulty in adhering to fluid restrictions and diabetes. Twenty-two (22) consequents were also identified, in which weight gain in a short period, cardiovascular diseases and increased blood pressure were those with a higher prevalence.

In conducting this analysis, it became clear that the definition evidenced by the NANDA International taxonomy for the Excess fluid volume nursing diagnosis and the components of this diagnosis (defining characteristics and related factors) need further complementation, seeking to better attend patients with Chronic Kidney Disease undergoing dialysis therapy, thus ratifying the hypothesis that there are further components beyond those presented by the NANDA International as elements of the Excess fluid volume diagnosis. 
RESUMO

Objetivo: Analisar o conceito sobrecarga de líquidos em pacientes com doença renal crônica em terapia dialítica e compará-lo ao diagnóstico de enfermagem Volume de líquidos excessivo presente na NANDA Internacional. Método: Revisão integrativa da literatura realizada nas bases LILACS, CINAHL e SCOPUS. Resultados: Obteve-se uma amostra de 22 artigos. Os atributos definidores do conceito foram: retenção de fluidos, acúmulo de fluidos no corpo e ganho de peso em um curto período, e compuseram a definição: retenção de fluidos no corpo (espaço intracelular/extracelular), expresso pelo ganho de peso em um curto período. Foram identificados 21 antecedentes e 22 consequentes da sobrecarga de líquidos em pacientes com doença renal em terapia dialítica. Conclusão: A definição evidenciada pela taxonomia da NANDA Internacional para o diagnóstico de enfermagem Volume de líquidos excessivo e os componentes desse diagnóstico carecem de uma complementação, com vistas a um melhor direcionamento do cuidado à clientela com doença renal em terapia dialítica.

\section{DESCRITORES}

Diagnóstico de Enfermagem; Doença Renal Crônica; Diálise Renal; Revisão.

\section{RESUMEN}

Objetivo: Analizar el concepto sobrecarga de líquidos en pacientes con enfermedad renal crónica en terapia dialítica y compararlo al diagnóstico de enfermería Volumen de líquidos excesivo presente en la NANDA Internacional. Método: Revisión integrativa de la literatura llevada a cabo en las bases LILACS, CINAHL y SCOPUS. Resultados: Se obtuvo una muestra de 22 artículos. Los atributos definidores del concepto fueron: retención de fluidos, acumulación de fluidos en el cuerpo y ganancia de peso en un corto período de tiempo, y compusieron la definición: retención de fluidos en el cuerpo (espacio intracelular/extracelular), expresado por la ganancia de peso en un corto período. Fueron identificados 21 antecedentes y 22 consecuentes de la sobrecarga de líquidos en pacientes con enfermedad renal crónica en terapia dialítica. Conclusión: La definición evidenciada por la taxonomía de la NANDA Internacional para el diagnóstico de enfermería Volumen de líquidos excesivo y los componentes de ese diagnóstico carecen de una complementación, con vistas a un mejor direccionamiento del cuidado al público con enfermedad renal en terapia dialítica.

\section{DESCRIPTORES}

Diagnóstico de Enfermería; Enfermedad Renal Crónica; Diálisis Renal; Revisión.

\section{REFERENCES}

1. NANDA International. Nursing diagnoses: definitions and classification 2015-2017. 10a ed. Oxford: Wiley Blackwell; 2015.

2. Fernandes MICD, Medeiros ABA, Macedo BM; Vitorino ABF, Lopes MVO, Lira ALBC. Prevalence of nursing diagnosis of fluid volume excess in patients undergoing hemodialysis. Rev Esc Enferm USP. 2014;48(3):446-53. DOI: http://dx.doi.org/10.1590/S0080-623420140000300009

3. Fernandes MICD, Bispo MM, Leite EMD, Lopes MVO, Silva VM, Lira ALBC. Diagnostic accuracy of the defining characteristics of the excessive fluid volume diagnosis in hemodialysis patients. Rev Latino Am Enfermagem. 2015;23(6):1057-64.

4. Lopes MVO, Silva VM, Araujo T L. Validação de diagnósticos de enfermagem: desafios e alternativas. Rev Bras Enferm. 2013;66(5):649-55.

5. Walker LO, Avant KC. Strategies for theory construction in nursing. 5a ed. Upper Saddle River: Pearson/Prentice Hall; 2011.

6. Whittemore R, Knafl K. The integrative review: updated methodology. J Adv Nurs. 2005;52(5):546-53.

7. Joanna Briggs Institute. Levels of evidence. Adelaide: University of Adelaide; 2014.

8. Lettgen B, Bald M, Valleé H, Bonzel KE, Rascher W. Atrial natriuretic peptide and cyclic 3'5'-guanosine monophosphate as indicators of fluid volume overload in children with chronic renal failure. Pediatr Nephrol. 1992;6(1):60-4.

9. Everett KD, Brantley PJ. The relation of stress and depression to interdialytic weight gain in hemodialysis patients. Behav Med. 1995;21(1):25-30.

10. Leypoldt JK, Cheung AK, Delmez JA, Gassman JJ, Levin NW, Lewis JAB, et al. Relationship between volume status and blood pressure during chronic hemodialysis. Kidney Int. 2002;61(1):266-75.

11. Giaramazid TA Ciovreki AL, Morfakidou LC, Iliou CP, Karapanagiotou P. A study of dietary knowledge and its religious relationship in patients receiving haemodialysis. EDTNA ERCA J. 2005;31(4):199-202.

12. Gan $\mathrm{H}$, Chen M, Lindholm B, Wang T. Volume control in diabetic and nondiabetic peritoneal dialysis patients. Int J Nephrol Urol. 2005;37(3):575-9.

13. Broscious SK, Castagnola J. Chronic kidney disease acute manifestations and role of critical care nurses. Crit Care Nurse. 2006;26(4):17-20, $22-8$.

14. Gonçalves S, Pecoits-Filho R, Perreto S, Barberato SH, Stinghen AEM, Lima EGA, et al. Associations between renal function, volume status and endotoxaemia in chronic kidney disease patients. Nephrol Dial Transplant. 2006;21(10):2788-94.

15. Headley CM, Wall BM. Flash pulmonary edema in patients with chronic kidney disease and end stage renal disease. Nephrol Nurs J. 2007;34(1):15-37.

16. Kalantar-Zadeh K, Regidor DL, Kovesdy CP, Wyck DV, Bunnapradist S, Horwich TB, et al. Fluid retention is associated with cardiovascular mortality in chronic hemodialysis patients. Circulation. 2009;119(5):671-9.

17. Lindberg M, Prutz KG, Lindberg P, Wikstrom B. Interdialytic weight gain and ultrafiltration rate in hemodialysis: Lessons about fluid adherence from a national registry of clinical practice. Hemodial Int. 2009;13(2):181-8.

18. Lindberg M, Wikstrom B, Lindberg P. Subgroups of haemodialysis patients in relation to fluid intake restrictions: a cluster analytical approach. J Clin Nurs. 2010;19(21):2997-3005.

19. Noble H, Meyer J, Bridge J, Johnson B, Kelly D. Exploring symptoms in patients managed without dialysis: a qualitative research study. J Ren Care. 2010;36(1):9-15.

20. Walsh E, Lehane E. An exploration of the relationship between adherence with dietary sodium restrictions and health beliefs regarding these restrictions in Irish patients receiving haemodialysis for end-stage renal disease. J ClinNurs. 2011;20(3-4):331-40. 
21. Papakrivopoulou E, Lillywhite S, Davenport A. Is N-terminal probrain-type natriuretic peptide a clinically useful biomarker of volume overload in peritoneal dialysis patients? Nephrol Dial Transplant. 2012;27(1):396-401.

22. Choi SH, Shin DS, Jung ES, Kim AJ, Park H, Sung J, et al. Prognostic implication of interdialytic fluid retention during the beginning period in incident hemodialysis patients. Tohoku J Exp Med. 2012;226(2):109-15.

23. Aliasgharpour M, Shomali M, Moghaddam MZ, Faghihzadeh S. Effect of a self-efficacy promotion training programme on the body weight changes in patients undergoing haemodialysis. J Ren Care. 2012;38(3):155-61.

24. Elias RM, Bradley TD, Kasai T, Motwani SS, Chan CT. Rostral overnight fluid shift in end-stage renal disease: relationship with obstructive sleep apnea. Nephrol Dial Transplant. 2012;27(4):1569-73.

25. Antlanger M, Hecking M, Haidinger M, Werzowa J, Kovarik JJ, Paul G, et al. Fluid overload in hemodialysis patients: a cross sectional study to determine its association with cardiac biomarkers and nutritional status. BMC Nephrol. 2013;14:266.

26. Xu Y, Chen Y, Li D, Li J, Liu X, Cui C, et al. Hypertension, fluid overload and micro inflammation are associated with left ventricular hypertrophy in maintenance hemodialysis patients. Ren Fail. 2013;35(9):1204-9.

27. Tsai Y, Tsai J, Chen S, Chiu Y, Hwang S, Hung C, et al. Association of fluid overload with kidney disease progression in advanced CKD: a prospective cohort study. Am J Kidney Dis. 2014;63(1):68-75.

28. Cabrera C, Brunelli SM, Rosenbaum D, Anum E, Ramakrishnan K, Jensen DE, et al. A retrospective, longitudinal study estimating the association between interdialytic weight gain and cardiovascular events and death in hemodialysis patients. BMC Nephrol. 2015;16:113.

29. Wong MMY, McCullough KP, Bieber BA, Bommer J, Hecking M, Levin NW, et al. Interdialytic weight gain: trends, predictors, and associated outcomes in the international dialysis outcomes and practice patterns study (DOPPS). Am J Kidney Dis. 2017;69(3):367-79.

30. Leite EMD, Araujo MGA, Fernandes MICD, Tinoco JDS, Lucio KDB, Lira ALBC. Hydration class of NANDA International in patients undergoing hemodialysis: a cross-sectional study. Online Braz J Nurs [internet] 2015 [cited 2016 Aug 29];14 Suppl:515-24. Available from: http://www.objnursing.uff.br/index.php/nursing/article/view/4892.

31. Ameson TJ, Liu J, Qiu Y, Gilbertson DT, Foley RN, Collins AJ. Hospital treatment for fluid overload in the medicare hemodialysis population. Clin J Am Soc Nephrol. 2010;5(6):1054-63.

32. Brasil. Ministério da Saúde; Secretaria de Atenção à Saúde, Departamento de Atenção Especializada e Temática. Diretrizes clínicas para o cuidado ao paciente com doença renal crônica - DRC no Sistema Único de Saúde [Internet]. Brasília: Ministério da Saúde; 2014 [citado 2016 ago. 29]. Disponível em: http://sonerj.org.br/wp-content/uploads/2014/03/diretriz-cl-nica-drc-versao-final2.pdf

33. Penne EL, Levin NW, Kotanko P. Improving volume status by comprehensive dietary and dialytic sodium management in chronic hemodialysis patients. Blood Purif. 2010;30(1):71-8.

34. Covic A, Voroneanu L, Locatelli F. Uraemic toxins versus volume and water as the major factor that matters with dialysis. Nephrol Dial Transplant. 2012;27(1):58-62. 